\title{
Soil Health Assessment and Its Sustenance
}

\author{
Radhika Mankotia, Rakesh Sharma, Swapana Sepehya, Raj Saini and Anil Kumar*
}

Department of Soil Science \& Water Management, College of Horticulture \& Forestry, Dr. YS Parmar University of Horticulture \& Forestry, Neri, Hamirpur, H.P. 171001, India

*Corresponding author

\begin{tabular}{l} 
K e y w o r d s \\
Health, Indicators, \\
Assessment, \\
Sustenance, \\
Functions, Soil \\
\hline Article Info \\
\hline $\begin{array}{l}\text { Accepted: } \\
15 \text { July } 2019 \\
\text { Available Online: } \\
\text { 10 August } 2019\end{array}$ \\
\hline
\end{tabular}

A B S T R A C T

One of the most buzz phrase in agriculture is the term "Soil Health". Soil health - the continued ability of a soil to sustain crop growth over the longterm through efficient recycling and provision of nutrients, water and is controlled by a variety of factors and their interactions, including soil physical and chemical properties, soil organic matter and the activities of diverse soil biological communities. The health of soil determines agricultural sustainability. A healthy soil - supposed to have values of key soil functions in the desirable and optimum range. The soil functions can be weighted according to the relative importance of each function in fulfilling the management goals based on expert opinions. For assessing the soil health, method like Minimum Data Set should be adopted. Since an empty soil cannot support or give rise to a high civilization and culture, there is a need for holistic management approaches for sustenance of soil health which optimize the multiple functions of soil, conserve soil resources, support strategies for promoting soil health is importantt.

\section{Introduction}

Soil health assessment and its sustenance is one of the major factors for sustainable agriculture. A good soil health is essential to maintain and sustain high crop productivity and produce quality. In Indian context, soil health decline has been reflected concerning multiple nutrient deficiencies in crop production systems and reducing fertilizer response ratio. Soil health decline is caused by soil erosion, nutrient mining, reduced use of organics and imbalances in the fertilizer use. Thus, a holistic approach involving the possible sources and best management practices are needed. The strategy to improve soil health should be based on soil test based integrated nutrient management, promotion of balanced fertilization, use of crop residues, conservation agriculture and finding methods to incorporate organic matter into the soil.

Periodic assessment of soil health with new tools and techniques is equally important. 


\section{Soil health}

Soil health is defined as being a state of dynamic equilibrium between flora, and fauna and their surrounding soil environment in which all the metabolic activities of the former proceed optimally without any hindrance, stress or impedance from the latter (Goswami and Rattan, 1992).

Healthy soils maintain community of soil organisms that help to control plant disease, insect and weed pests, recycle essential plant nutrients, improve soil structure, and ultimately improve crop production (FAO, 2008).

Assessment and quantification of soil health requires measurement of multiple chemical, physical and biological soil properties, referred to as soil health indicators (MoebiusClune et al., 2016).

\section{Soil multiple functions}

Soil performs various functions as follows:

Serves as a medium for plant growth

Function as a global storage and cycling of nutrients

Act as an environmental filter

Maintain human and animal health

Regulate flow of water in the environment Provide support for construction

Thus soil not only supply nutrients but also offers favorable physio-chemical conditions for plant growth, promote and sustain crop production, provide habitat for soil organisms, ameliorate environmental pollution, resist degradation and maintain or improve human and animal health.

\section{Importance of soil health}

Soil, water, and air all are essential to human life and society but of these threes, soils often the forgotten component. Soils are the basis for our sustainable food system for healthy lives. Soils produce $95 \%$ of our food and at the same time, soil provides living space for humans, essential ecosystem services like regulation and supply of water, climate regulation, biodiversity conservation, improving resilience to floods and droughts, carbon sequestration and cultural services.

A healthy soil is "fit for purpose" this means it is easy to work, friable, holds water and nutrients well and has good drainage capacity. It allows for healthy root growth and good crop establishment. A healthy soil saves effort and money. But still the multiple functions of soil often go unnoticed because soils don't have a voice.

\section{Characteristics of healthy soil}

Good soil tilth - Soil tilth refers to overall physical character of the soil in the context of its suitability for crop production. Soil with a good tilth is well-structured, dark with organic matter, crumbly, and has no large and hard clods.

Sufficient depth - Sufficient depth refers to the extent of the soil profile through which roots are able to grow to find water and nutrients. A shallow depth soil is more susceptible to damage in weather fluctuations.

Sufficient nutrients supply - An adequate and accessible supply of nutrients is necessary for optimal plant growth and for maintaining balanced cycling of nutrients within the system. An excess of nutrients can lead to leaching and potential ground water pollution, high nutrient runoff as well as toxicity to plants and microbial communities. 
Small population of insects, pests, and pathogens - Plant pathogens, pests, and insects can cause disease and damage to the crop. In a healthy soil, the population of insects, pests, and pathogens is low or is less active.

Large population of beneficial organisms Soil organisms are important to the functioning of the soil.

They help with cycling nutrients, decomposing organic matter, maintaining soil structure, biologically suppressing plant pests. A healthy soil will have a more population of beneficial organisms.

Low weed pressure - Weed pressure is a major constraint in crop production. Weeds compete with the crops for the available water, and nutrients that are essential for plant growth. Weeds can block sunlight, interfere with crop, harvest and cultivation operations.

Resistant to degradation - A healthy, well aggregated soil full of beneficial microbial communities are more resistant to adverse conditions like erosion by wind and rain, excess rainfall, extreme drought, vehicle compaction and disease outbreak.

Good water storage and good drainage During heavy rain, a healthy soil has large, stable pores to take in water.

\section{Soil health assessments}

Soil health assessment is how wells soil performs all of its functions. Soil health cannot be determined by just measuring crop yield, water quality or any other outcome. As we know, soil have chemical, biological, and physical properties, which interact in a hastily manner to give, soil its capacity to function or perform. Thus, soil capacity cannot be measured directly, but must be inferred from measuring changes in its attributes or attributes of the ecosystem, referred to as indicators. Indicators are a composite set of measurable attributes which are derived from functional relationships and can be measured by field observations, field sampling, remote sensing, survey or compilation of existing information.

\section{Soil indicators should}

Be easily measured

Combination of soil physical, chemical, and biological properties, and process

Sensitive enough to detect change in management practice

Be stable in short term weather patter to enable measurement

Have low error associated with measurement

Have expected or threshold values

Have community acceptance and involvement

Be cost effective

The indicators used by different researchers or in different regions may not be the same because soil health assessment is purposeoriented and site-specific.

\section{Classification of indicators}

Soil health indicators may directly monitor the soil, or monitor the outcomes that are affected by the soil such as productivity, vegetation, water, and air quality. The indicators (Figure 1) that directly monitor the soil is grouped as

Visual

Chemical

Physical and

Biological indicators 
The indicators that indirectly monitor the soil health are: crop yield/ unit area/ unit time, plant biomass/unit area/unit time, legume/nolegumes crop ratio, water use efficiency/unit time/ unit use of nutrients, and produce quality, such as cereal grain protein, concentration of toxic elements in food grains, vegetables, fruits, etc. (Lal, 1994).

Visual indicators: Visual indicators are obtained from observation of soil, subsoil, change in soil color, ephemeral gullies, pounding, runoff, plant response, and weed species. Visual evidence can be a clear indication that soil health is threatened or changing.

Chemical indicators: Chemical indicators include soil $\mathrm{pH}$, electrical conductivity, adsorption and cation exchange capacity, organic matter, available nutrients, soil acidification (surface and sub-surface), soil salinization, exchangeable sodium (soil structural stability).

Physical indicators: Physical indicators include pore size distribution, aggregate stability, saturated hydraulic conductivity, infiltration, bulk density, and surface crust, rooting depth, buffering against water, air, and nutrient stress.

Biological indicators: Biological indicators include potentially mineralize $\mathrm{N}$, soil microbial biomass and/or respiration, fatty acid profile, enzyme activity, or microbial biodiversity, nematode communities, and earthworm populations.

\section{Quantitative assessment of soil health}

The assessment of soil health involved three main steps

Selection of appropriate indicators for Minimum Data Set
Transformation of indicator values to scores

Integration of scores into index

Selection of appropriate indicators for Minimum Data Set (MDS)

Although some indicators of soil health may be sensitive to change, another may be more stable, the question arises whether these indicators are measurable and how to develop them into a soil health index. A valid soil health index, interpret data from soil measurements and show whether management, land use processes are having the desired results or not. Both quantitative and qualitative soil health indices have been proposed. Qualitative measures of soil health tends to be more subjective in their measurement, but can be assessed more easily. A concept for quantifying soil health by expressing soil health as a function of measurable soil attributes were suggested by (Larson and Pierce, 1991). They also measured the changes in soil health over time and proposed the use of minimum data set of measured soil properties. A framework for the evaluation of soil health based on function of soil with respect to sustainable production, environmental quality, human, and animal health was presented by Doran and Parkin (1994). A frame work for quantifying soil health using multi-objective analysis principles of systems engineering was developed (Karlen and Scott, 1994). They defined critical soil functions and potential chemical, and physical indicators of those functions.

\section{Transformations of indicator values to scores}

After determining the variables for the minimum data set, every observation of each MDS indicator is transformed, generally into two techniques. 
Linear scores: Indicators are ranked in ascending and descending order depending on whether a higher value is considered good or bad regarding soil functions.

Non-linear scores: The indicators are transformed using non-linear scoring functions using curve fit equation.

The shape of each decision function can be:

A bell-shaped curve

A sigmoid curve with an upper asymptote (more is better)

A sigmoid curve having a lower asymptote (less is better)

\section{Integration of scores into index}

Integration of the scores into index can be simple or weighted.

\section{Simple integration}

Adjusted according to site

Based on priority ranks

\section{Weighted integration}

The weights based on the importance of each indicator can be assigned (Figure 2).

\section{Soil testing laboratories}

Soil testing is important to diagnose status of the physical, chemical and biological properties of the soil and to assess the quantity of available nutrients and productivity of the soils. Soil testing helps farmers to judge the suitability of land for agriculture, identify and quantify the constraining factors of cropproductivity. Soil testing mostly covers only chemical parameters, viz. soil $\mathrm{pH}, \mathrm{EC}$ and available nutrients. However, the soil test reports are confined to only available NPK status, and $\mathrm{pH}$ or EC and thus do not provide a comprehensive picture of soil health. Therefore, it is essential to include more parameters like micro nutrients, soil physical and soil biological parameters in soil testing laboratories.

\section{Soil health test kits}

The soil health test kits may provide a quick and easy route to have an idea about key soil properties. As compared to elaborate and routine laboratory test, kits save time and labor and may give fairly accurate estimates for selected soil properties. Most of these kits perform qualitative or semi-quantitative assessment of soil fertility involving the use of color charts, manual shaking and scooping.

All these steps are subjective and introduce error at several stages, therefore it does not give complete quantitative soil fertility evaluation. Hence, it is important to develop some low cost, rapid, farmer-friendly mini laboratories which could meet the needs of soil health assessment.

\section{Mridaparikshak (Mini soil testing lab)}

Indian Institute of Soil Science, Bhopal, has developed "Mridaparikshak". Mridarparikshak is a mini laboratory that helps to estimate 10 important soil parameters viz., pH, EC, organic carbon, nitrogen, phosphorus, potassium, sulphur, zinc, iron, and boron. This is a digital mobile quantitative soil test mini lab to provide soil testing service at farmer's doorstep. It is compatible with soil health cards. It comes with smart soil-pro, an instrument for determining soil parameters and displaying of fertilizer nutrient recommendations. Also, this mini lab is supplied with electronic weighing balance, sieves, shaker, hot plate. Further the results of this mini lab can be disseminated quickly to 
farmers via SMS. It can be operated by young educated farmers/rural youth with a short training.

\section{Methods for sustenance of soil health}

\section{Reduced tillage}

Enhance soil quality

Conserve soil organic matter

Conserve soil moisture

Reduces erosion

Controls weed

Maintain crop yields

Improves soil aeration

Reduces fuel use

Rasmussen (1999), studied the impact of ploughless soil tillage on yield and soil quality, and found out that reduced tillage increased the volume of water-holding pores. Reduced tillage lead to increased activity and biomass of earthworms.

It also protected soil against erosion of soil particles and nutrients. It also resulted in reduced leaching of nitrogen.

Chan et al., (2002), studied soil carbon fractions and relationships to soil quality under different tillage and stubble management, and found out that tillage removed mainly particulate organic carbon which accounted for $80 \%$ of the total carbon loss.

\section{Cover crops}

Prevents soil erosion

Reduces leaching of nutrients

Alleviates soil compaction

Suppress weed growth

Conserves soil moisture

Improves water infiltration

Nyakatawa et al., (2001), studied tillage, cover cropping, and poultry litter effects on selected soil chemical properties and found that cover crops rapidly increased surface soil organic matter, soil water conservation, crop growth, and seedling establishment.

\section{Mulching}

Reduces soil erosion from wind and rain

Conserves water

Increases soil organic matter

Control weeds

Congenial environment to microbes

Regulate soil temperature

Ma et al., (2018), studied the impact of plastic film mulching on crop yields, soil water, nitrate, and organic carbon and found out plastic film mulching increases crop yields.

Chakraborty et al., (2008), studied the effect of mulching on soil and plant water status, and found that rice husk provided a better soil environment as compared to polyethylene mulch in terms of moisture retention, water use efficiency and soil temperature.

\section{Crop rotation}

Increases nutrient cycling

Manages plants pests and insects

Adds diversity so soil microbes can thrive

Improves nutrient use efficiency

Decreases use of pesticides

Improves water quality

Congreves et al., (2015), studied the long term impact of tillage and crop rotation on soil health and found that crop rotation resulted in aggregate stability, $\mathrm{N}$ mineralization, and increased yield.

Wilson and Al-Kaisi (2008), studied the crop rotation effect on soil carbon dioxide emissions and found that crop rotation have impact on both the rate and cumulative soil carbon dioxide emission. 
Fig.1 Most commonly used soil health indicators reported by Thakur and Sharma (2019)
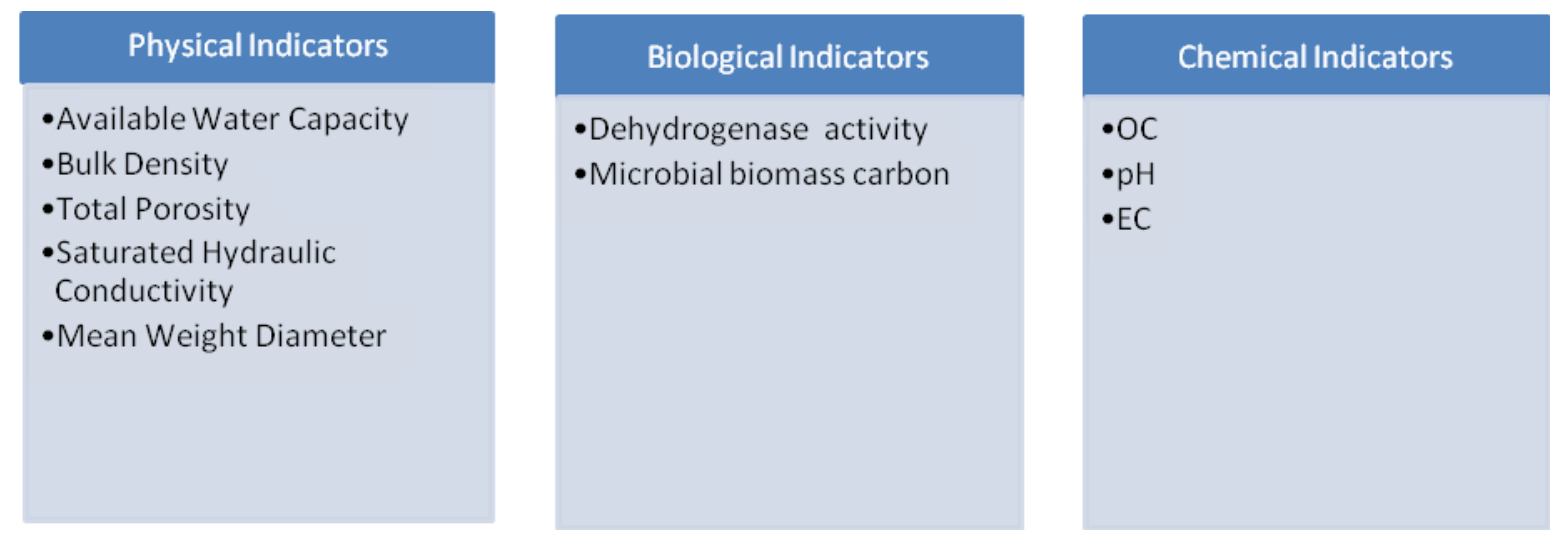

Fig.2 Schematic diagram of Soil Management Assessment Framework reported by Andrews et al., 2001

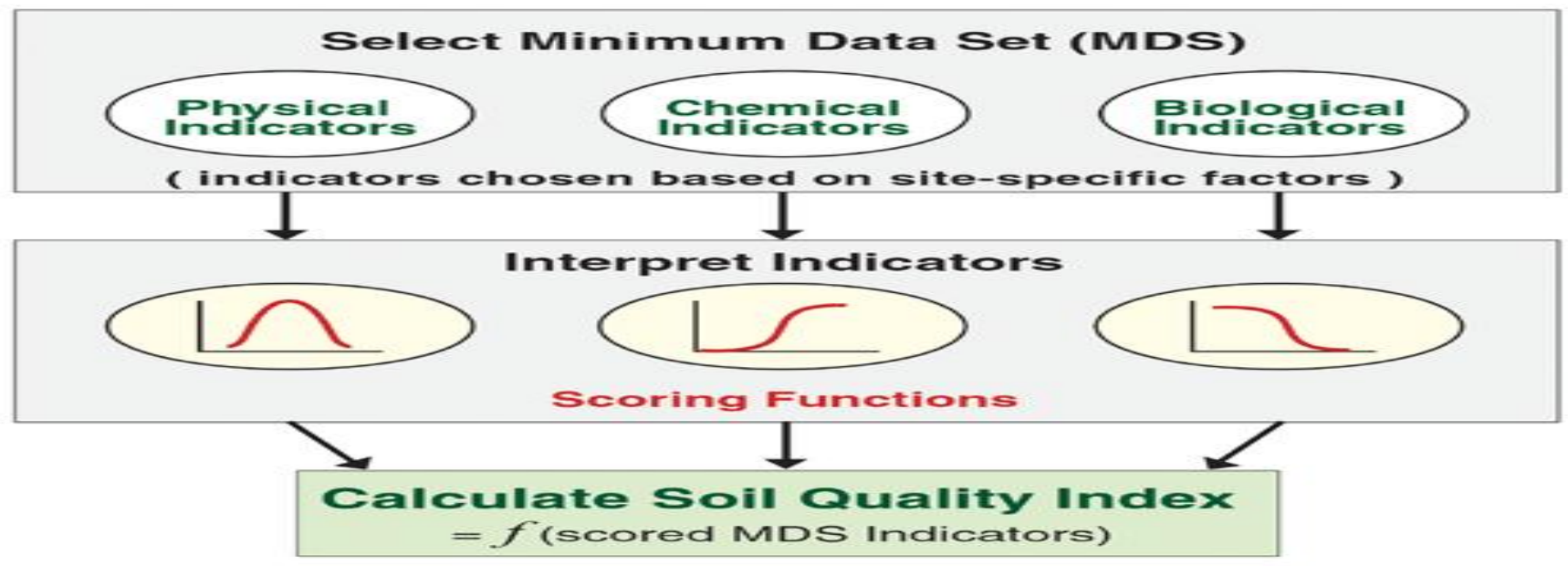

Soil health sustenance planning process

Determine field background- field operation type, equipment, access to resources, situational opportunities and limitations

Set goals and decide on number of soil health samples according to objective

For each management unit identify and explain constraints and prioritize

Identify feasible management options

Create soil health management plan
Implement and document management practices, monitor progress, repeat testing, and evaluate outcomes

Adapt the plan based on experience and data over time

\section{Initiatives taken by Government of India to} improve soil health

\section{Soil health management scheme (SHMS)}

SHMS is the invention under National Mission for Sustainable Agriculture. SHMS aims at promoting Integrated Nutrient Management (INM) through: 
Judicious use of chemical fertilizers including secondary and micro nutrients in conjunction with organic manures and bio-fertilizers for improving soil health and its productivity

Strengthening of soil and fertilizer testing facilities to provide soil test based recommendations to farmers for improving soil fertility

Ensuring quality control requirements of fertilizers, bio-fertilizers, and organic fertilizer under fertilizer control order, 1985

Up gradation of skill and acknowledge of soil testing laboratory staff, extension staff

Farmers through training and demonstrations, promote organic farming practices

\section{Soil health card scheme}

In February 2015, a scheme was launched by central government "Soil health card scheme". Under this scheme the government plans to issue soil health card to farmers to help them get a good harvest by studying the quality of soil. The major components of the scheme are:

Issue of Soil health cards

Training for soil analysis.

Financial assistance for package of nutrient recommendations

Capacity building and regular monitoring and evaluation

Constitution of the Project management team (PMT)

\section{Results and Discussions}

Soil scientists and production agronomists, in collaboration with colleagues in other disciplines have developed various strategies that contribute in improving soil health. If soil health is improved, we shall simultaneously achieve the other goals like food quality/safety, environmental quality and human/animal health as well. While, soil health has been improved by some intensified systems others have degraded soil, water, and atmospheric resources. As routine laboratory analysis of soil health is very expensive and time-consuming, more emphases is to be given on fair good suitable indicators. Although many indicators and indices have been proposed, there is a need of a globally acceptable and applicable definition and methodology of assessment of soil health are still not in place. Deteriorating soil health is the main cause of poor soil structure, reduced productivity and profitability. To mitigate the ill-effects on soil health and to protect the soil and land resource, it is important to give more focus on soil sustenance practices including conservation tillage, crop residue retention and recycling, effective crop rotations by way of including legumes in cropping systems, addition of animal based manures, adoption of soil water conservation practices, land cover management and mulching of soils with insitu grown and externally brought plant and leafy materials, etc.

\section{Acknowledgments}

I wish to express my sincere gratitude to Dr. Rakesh Sharma, Department of Soil Science and Water Mangement for providing me an opportunity to write this review article. I sincerely thank Dr. Swapana Sepehya, Dr. Anil Kumar, Dr. Raj Saini for their guidance and encouragement in carrying out this review article. I also wish to express my gratitude to the professors and other staffs members of College of Horticulture and Forestry Neri, Hamirpur (H.P) who rendered their help during the period of my work. 


\section{References}

Andrews, S.S., Karlen, D.L., Mitchell, J.P., 2001. A comparison of soil quality indexing methods for vegetables production systems in Northern California. Agriculture, Ecosystems and Environment 1760, 1-21.

Chakraborty, D., Nagarajan, S., Aggarwal, P., Gupta, V.K., Tomar, R.K., Garg, R.N., Sahoo, R.N., Sarkar, A., Chopra, U.K., Sharma, K.S.S., Kalra, N., 2008. Effect of mulching on soil and plant water status, and the growth and yield of wheat (Triticum aestivum L.) in a semiarid environment. Agricultural Water Management 95, 1323-1334.

Chan, K.Y., Heenan, D.P., Oates, A., 2002. Soil carbon fractions and relationship to soil quality under different tillage and stubble management. Soil \& Tillage Research 63,133-139.

Congreves, K.A., Hayes, A., Verhallen, E.A., Eerd, L.L.V., 2015. Long-term impact of tillage and crop rotation on soil health at four temperate agroecosystems. Soil \& Tillage Research 152, 17-28.

Doran, J.W., Parkin, T.B., 1994. Defining and assessing soil quality. In Defining Soil Quality for Sustainable Environment (J.W Doran, D.C. Coleman, D.F. Bezdicek, and B.A. Stewart, Eds). Pp.321. Soil Science Society of America, Special Publication. No 35. ASA, CSSA and SSSA, Madison, WI.

FAO, 2008. An international technical workshop: Investing in sustainable crop intensification. The case for improving soil health. In Integrated Crop Management. Vol.6. FAO, Rome, pp.149.

Goswami, N.N., Rattan, R.K., 1992. Soil Health- Key to sustained agriculture productivity. Fertiliser News 37(123), 53-60.
Karlen, D.L., Scott, D.E., 1994. A framework for evaluating physical and chemical indicators of soil quality. In Defining Soil Quality for Sustainable Environment (J.W Doran, D.C. Coleman, D.F. Bezdicek, and B.A. Stewart, Eds). pp. 53 -72. Soil Science Society of America, Special Publication. No 35. ASA, CSSA and SSSA, Madison, WI.

Lal, R., 1994. Method and guidelines for assessing sustainable use of soil and water resource in the tropics. SCS technical monograph. No.21. Soil Management Support Services, Washington, DC, 78pp.

Larson, W.E., Pierce, F.J., 1991. Conservation and enhancement of soil quality In Evaluation for sustainable land management in the developing world. Vol. 2: Technical papers (J. Dumanski, E. Pushparajah, M. Latham, and R. Myers, Eds.). Proceeding International Workshop, Chiang Rai, Thailand. 15-21 September, 1991, pp. 175-203.

Ma, D., Chen, L., Qu, H., Wang, Y., Misselbrook, T., Jiang, R., 2018. Impacts of plastic film mulching on crop yields, soil water, nitrate, and organic carbon in Northwestern China: A meta-analysis. Agricultural Water Management 202, 166-173.

Moebius-Clune, B.N.., Moebius-Clune, D.J., Gugino, B.K., Idowu, O.J., Schindelbeck, R.R., Ristow, A.J., van Es, H.M., Thies, J.E., Shayler, H.A., McBride, M.B., Wolfe, D.W., Abawi, G.S., 2016. Comprehensive Assessment of Soil Health: The Cornell Framework Manual, 3.1 ed.

Nyakatawa, E.Z., Reddy, K.C., Sistani, K.R., 2001. Tillage, cover cropping, and poultry litter effects on selected soil chemical properties. Soil \& Tillage Research 58, 69-79. 
Rasmussen, K.J., 1999. Impact of ploughless soil tillage on yield and soil quality. Soil \& Tillage Research 53, 3-14.

Thakur, N., Sharma, R., 2019. Soil Quality. International Journal of Current Microbiology and Applied Sciences 8(7): 2920-2930.
Wilson, H.M., Al-Kaisi, M.M., 2008. Crop rotation and nitrogen fertilization effect on soil carbon dioxide emissions in central Lowa. Applied Soil Ecology 39, 264-270.

\section{How to cite this article:}

Radhika Mankotia, Rakesh Sharma, Swapana Sepehya, Raj Saini and Anil Kumar. 2019. Soil Health Assessment and Its Sustenance. Int.J.Curr.Microbiol.App.Sci. 8(08): 1978-1987. doi: https://doi.org/10.20546/ijcmas.2019.808.231 